๑ Entomologica Fennica. 5 December 1995

\title{
Bumblebee visits to different colour morphs of the Washington lupine, Lupinus polyphyllus
}

\author{
Inari Pohtio \& Ilkka Teräs
}

Pohtio, I. \& Teräs, I. 1995: Bumblebee visits to different colour morphs of the Washington lupine, Lupinus polyphyllus. — Entomol. Fennica 6:139-151.

We examined the flower visits of bumblebees (Hymenoptera, Apoidea, Bombus spp.) to Lupinus polyphyllus Lindley (Fabaceae) in southern Finland. The racemes of the plant bear nectarless flowers which appear in three main colour morphs, blue, red and white, of which blue is the most common. Blue inflorescences had the greatest number of flowers and their proportion increased towards the end of the flowering period, whereas white flowers seemed to fade away more quickly and drop easier than those of the other morphs. Bumblebees seemed to prefer blue inflorescences over red and white in the beginning of the flowering period, but in the end of the period red and white inflorescences were visited more often than expected on the basis of their proportion in the field. Bumblebee species differed slightly in their colour preferences, for instance, B. lapidarius seldom visited white flowers. When the temperature was low and the wind was high, the visits to blue flowers were more numerous than expected, whereas in cloudy conditions red flowers were often visited. Bumblebees moved between the same coloured inflorescences more often than expected, because the colour selected in the beginning was favoured during the whole foraging trip and the nearest inflorescence having another colour was skipped. The pollinator behaviour favoured the existing proportions of colour morphs in the lupine populations.

Inari Pohtio \& Ilkka Teräs, Department of Ecology and Systematics, P.O. Box 17, FIN-00014 University of Helsinki, Finland

\section{Introduction}

The Washington lupine, Lupinus polyphyllus Lindley, is an introduced perennial plant originally from the western parts of North America. In Europe, it has been a common horticultural plant for a long time and has a large distribution area in south and central Finland (Jalas 1965), especially along roadsides.
Individual lupine plants have many inflorescences (or racemes) $60-120 \mathrm{~cm}$ high, each with 100-200 flowers. The flowers are arranged in whorls, and the buds in the bottom of the inflorescence open first (Haynes \& Mesler 1984). Flowers are nectarless (Dunn 1956, Powell \& Jones 1983), but produce plenty of reddish yellow pollen.

According to Schaal (1980) and Williams (1987), lupines are pollinated mainly by bumble- 
bees (Bombus spp.), honeybees (Apis mellifera) and solitary bees (Hymenoptera: Apoidea). Flowers may be visited also by thrips, flies and butterflies, but these non-Hymenopteran insects are not capable of opening (tripping) the flower for proper pollination. In some lupine species selfpollination is possible, for the anthers hang near the stigma (Williams 1987), but lupine pollen grains are not carried by the wind, and therefore there is no indication of wind pollination (Langridge \& Goodman 1977).

Flowers of Lupinus polyphyllus appear in three main colour morphs, blue, red and white, although there is much variation in the details of the colouring. However, this is genetic polymorphism, because different flower colours coexist at higher frequencies than do those maintained by mutation (see Kay 1978). Normally, blue inflorescences dominate in most of the seminatural Lupinus polyphyllus populations in Finland (Jalas 1965), but the colour proportions may be different at least at the beginning of the local introduction.

The colour vision of bees has been reviewed by Kevan (1978). Bumblebees seem to visit flowers without colour preferences being innate (Brian 1957, Waser 1983a), although bees may learn to link the profitable flower and its colour (Kevan 1978 , Barth 1985). There is no general agreement as to the importance of flower colour when insects choose their foraging plants, but plants compete for the favour of pollen- transferring animals with their colourful flowers; such competition may be the reason for differences in colour morphs (Waser 1983b).

Bumblebees may prefer a certain flower colour; because they thus decrease the pollination success of the other colour morphs, the proportions of these morphs diminish from year to year. We address the following questions:

1) are the different colour morphs of lupine flowers visited in the same proportions as their proportions in the field?

2) if colours are not selected randomly, which is the colour (or colour combination) preferred during the flower visits?

3) are the possible flower colour preferences influenced by weather factors or time of day or week in summer?
The ultimate reason was to discover whether bumblebee visits maintained the existing colour proportions or favoured the shift towards the dominant colour (blue).

\section{Material and methods}

We examined the flower visits of bumblebees to different colour morphs of Lupinus polyphyllus in Espoo, southern Finland. Most of the observations were made in June 1989. In the main study area A (roadside at Olarinluoma, ca. $560 \mathrm{~m}^{2}$ ) there were about 1360 inflorescences (on average) in flower at that time. The smaller study plot B (garden at Iirislahti, ca. $30 \mathrm{~m}^{2}$ ) had only about 50 inflorescences in flower at the time. The colours of the flowers were categorized as seen by the human eye, not as seen by the insects (for the corresponding bee colours, see Daumer 1958). Furthermore, any ultraviolet cues or pollen guides were ignored. The post-pollination colour changes typical to many lupine species (Gori 1983, Powell \& Jones 1983) were not observed in L. polyphyllus.

In southern Finland the flowering of $L$. polyphyllus begins usually in the end of May and lasts $30-45$ days to the end of July, the main flowering period usually being in June. The Washington lupine blooms a second time about three months after its establishment in the spring (Aniszewski 1993), but we made no observations during the second period.

Bumblebee individuals were followed in the field at different times of the day. An individual was chosen randomly on an Lupinus polyphyllus patch where all three colour morphs were flowering and this bee was followed for as long as possible. The colours of the flowers, the number of flowers visited per inflorescence and the total time of visits were observed. The behaviour of 123 individual bumblebees in study area $\mathrm{A}$ and 144 individuals in area B was followed during their foraging trips (Table 1). The observation period per individual lasted from 3 to $3695 \mathrm{sec}-$ onds. In study area B bumblebees (128 individuals) were also observed for 10-minute periods four times a day on $1.5 \times 1.5 \mathrm{~m}$ squares.

All the individual bumblebees observed were collecting pollen, and as far as we could judge, 
none of them even tried to find nectar. The most common flower-visitor species was $B$. lucorum, but $B$. lapidarius and $B$. hypnorum, sometimes also $B$. pascuorum, $B$. subterraneus and $B$. pratorum were seen on the flowers (Table 1), whereas the long-tongued species $B$. hortorum (L.), although flying in the study areas, was not seen to visit lupine flowers. Most of the visitors were workers, but at the beginning of the flowering period queens were also observed. Besides bumblebees, also honeybees (Apis mellifera L.), cuckoo bumblebees (Psithyrus spp.), and syrphid flies were seen to visit lupine flowers.

Blue and red flowers open simultaneuosly, white flowers a few days later than the other morphs (Table 2). In study area A $95.5 \%$ of the inflorescences had blue, $3.5 \%$ red and $1 \%$ white flowers, on the average, during the study summer (1989). The proportion of blue inflorescences slightly increased towards the end of the blooming period, partly because of passing flower collectors who preferred to gather the colour morphs in equal numbers. In the study area B the proportions were different: $72 \%$ of the inflorescences had blue, $22 \%$ red and $6 \%$ white flowers. Also, in this area the proportion of blue inflorescences slightly increased during the summer (Fig. 1).

Blue inflorescences had the highest number of open flowers (up to 100). White flowers seemed to fade away in a shorter time than the other morphs, and therefore only about thirty white flowers were open at the time.

\section{Flower visits of bumblebees}

\subsection{Visits to inflorescences}

More than half of the bumblebee individuals $(\mathrm{N}=267)$ stayed with one flower colour (usually blue) during the foraging trip (or to be more exact, during the whole observation period). About $10 \%$ of the individuals visited all three colour morphs during the same trip, and $37 \%$ of

Table 1. Bumblebee species observed, abbreviations used in legends, length of proboscis in workers (in mm, Pekkarinen 1979), and number of individuals observed at Olarinluoma (study area A: IP in 1989, IT in 1989-94) and at lirislahti (study area B: IP in 1989).

\begin{tabular}{lrrrrr}
\hline & & \multicolumn{3}{c}{ Individuals } \\
Species & Abbr. & Proboscis length & A & B & Total \\
\hline Bombus hypnorum (L.) & hyp & 6.67 & 2 & 23 & 25 \\
B. lapidarius (L.) & lap & 6.96 & 66 & 10 & 76 \\
B. lucorum (L.) & luc & 6.37 & 53 & 98 & 152 \\
B. pascuorum (Scopoli) & pas & 7.89 & - & 11 & 11 \\
B. pratorum (L.) & pra & 7.11 & - & 2 & 2 \\
B. subterraneus (L.) & sub & 8.79 & 2 & - & 2 \\
Total no. of individuals & & & 123 & 144 & 267 \\
\hline
\end{tabular}

Table 2. Flowering of different colour morphs of Lupinus polyphyllus in study areas A (Olarinluoma) and B (lirislahti) during summer 1989.

\begin{tabular}{|c|c|c|c|c|c|c|}
\hline Flowering & blue & $\begin{array}{l}\text { A } \\
\text { red }\end{array}$ & white & blue & $\begin{array}{l}\text { B } \\
\text { red }\end{array}$ & white \\
\hline beginning & 26 May & 26 May & 30 May & 4 June & 4 June & 5 June \\
\hline $50 \%$ open & 5 June & 4 June & 5 June & 11 June & 6 June & 9 June \\
\hline $50 \%$ faded & 13 June & 18 June & $?$ & 20 June & 19 June & 27 June \\
\hline entirely faded & 27 June & $?$ & $?$ & ? & 2 July & 29 June \\
\hline
\end{tabular}



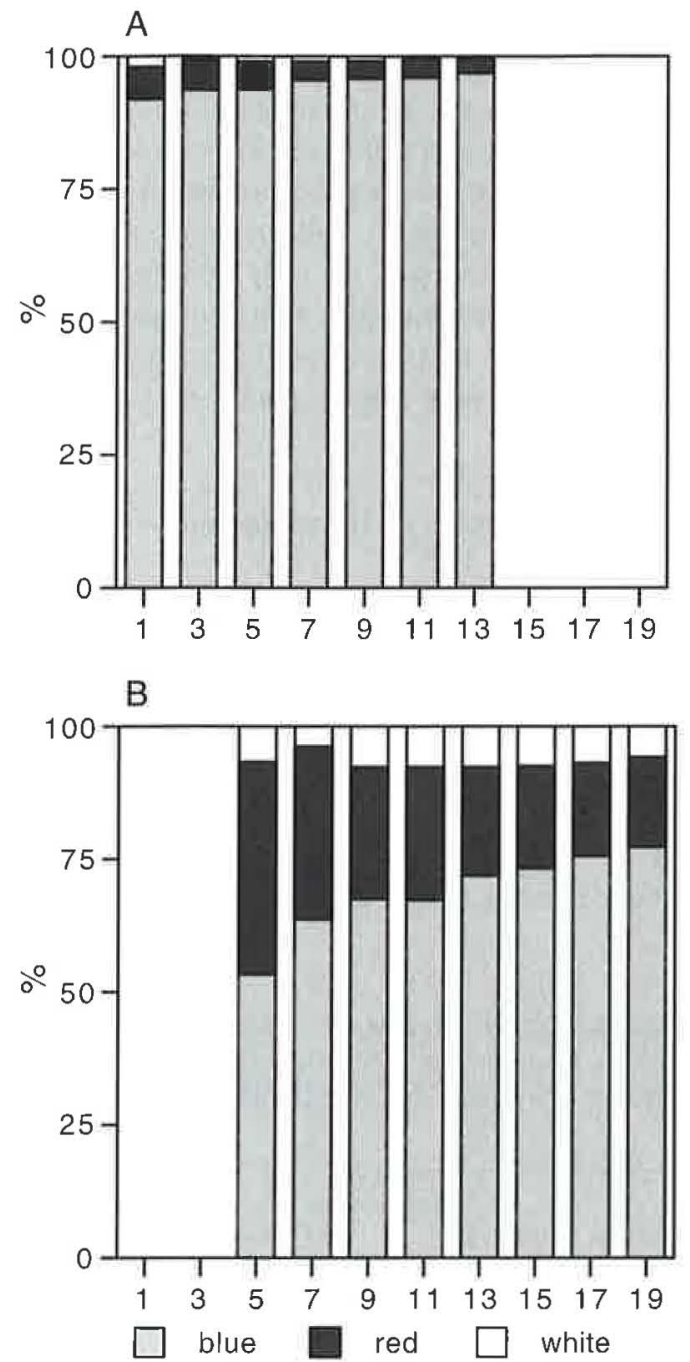

Fig. 1. Proportions of flowering inflorescences of Lupinus polyphyllus in study areas A (Olarinluoma) and B (lirislahti), June 1989. the individuals two colour morphs. All the flower colour combinations were observed except redwhite (Table 3 ).

In study area A (year 1989) individual bumblebees visited 884 inflorescences (Table 4). Of these visits $93.8 \%$ were paid to blue, $4.9 \%$ to red and $1.4 \%$ to white inflorescences. The proportion of visits did not differ significantly from the proportion of differently coloured inflorescences $\left(\chi^{2}=3.3\right.$, $\mathrm{df}=2, \mathrm{P}>0.1)$. The most common visitors were $B$. lucorum and $B$. lapidarius; the proportions of their visits to different colour morphs did not differ significantly $\left(\chi^{2}=1.2, \mathrm{df}=2, \mathrm{p}>0.5\right)$. In the beginning of the season blue inflorescences were favoured, in the end of the season red and white inflorecences were visited more often than expected from their share of the field.

In the study area $\mathrm{B}$ individual bumblebees visited 1964 inflorescences (Table 4). Of these visits $86.2 \%$ were paid to blue, $9.7 \%$ to red and $4.1 \%$ to white inflorescences. The proportion of visits differed significantly from the proportion of differently coloured inflorescences $\left(\chi^{2}=8.9\right.$, $\mathrm{df}=2, \mathrm{p}<0.05)$. The most common visitors were $B$. lucorum and B. pascuorum. All the bumblebee species except $B$. hypnorum visited blue inflorescences more often than expected. $B$. hypnorum clearly favoured red and white over blue and its difference from the behaviour of the other bumblebee species was highly significant $\left(\chi^{2}=14.2, \mathrm{df}=2, \mathrm{p}<0.001\right)$.

In study area $B$ many bumblebees, especially $B$. lucorum and B. hypnorum, seemed to pass by some inflorescences after their approach; the different colour morphs were "skipped" in the same proportions in which they were flowering.

Table 3. Colours of inflorescences ( $b=$ blue, $r=$ red, $w=$ white) visited by bumblebee individuals during one trip (observations from study areas A and $B$ combined).

\begin{tabular}{lrrrrrrrr}
\hline Species & $b$ & $r$ & $w$ & $b+r$ & $b+w$ & $r+w$ & $b+r+w$ & Total \\
\hline luc & 66 & 4 & 8 & 50 & 10 & - & 13 & 151 \\
lap & 42 & - & - & 25 & 4 & - & 5 & 76 \\
hyp & 11 & 1 & - & 6 & - & - & 7 & 25 \\
pas & 2 & 2 & - & 4 & 1 & - & 2 & 11 \\
pra & 1 & - & - & 1 & - & - & - & 2 \\
sub & 1 & - & - & 1 & - & - & - & 2 \\
Total & 123 & 7 & 8 & 87 & 15 & - & 27 & 267 \\
\hline
\end{tabular}


When bumblebees moved from one inflorescence to another (Table 5) they seem to select the same colour morph more often than expected in both study area $\mathrm{A}\left(\chi^{2}=146, \mathrm{df}=5, \mathrm{p}<0.001\right)$ and $\mathrm{B}\left(\chi^{2}=830, \mathrm{df}=8, \mathrm{p}<0.001\right)$. Especially movements from red to red and white to white were more common than expected in area $\mathrm{A}$ and movements from blue to blue in area $\mathrm{B}$. On the other hand, movements from blue to the other colours or vice versa were not as common as expected.

\subsection{Visits to flowers}

In study area $\mathbf{A}$, bumblebees visited differently coloured flowers as follows: $95.0 \%$ of the visits were paid to blue, $4.1 \%$ to red and $0.9 \%$ to white flowers $(\mathrm{N}=6306$, Table 6$)$. In this case $B$. lucorum and $B$. lapidarius had different preferences, for $B$. lapidarius favoured blue and $B$. lucorum red and white flowers $\left(\chi^{2}=21.9, \mathrm{df}=2\right.$, $\mathrm{p}<0.001)$

In study area B the flower visits of bumblebees divided as follows: $87.3 \%$ to blue, $8.8 \%$ to red and $3.9 \%$ to white flowers ( $N=14659$, Table 6). The preferences of different species seemed to differ. B. lapidarius and B. pascuorum avoided white flowers, while $B$. hypnorum favoured red and white and avoided blue flowers.

There were also differences between the bumblebee species in the mean numbers of inflorescences visited, flowers visited, and flowers visited per inflorescence (Table 7). In study area A the mean numbers of inflorescences visited and flowers visited were usually smaller than those observed in area $\mathrm{B}$, but, as a consequence, the numbers of flowers per inflorescence were greater (except in $B$. lucorum). However, especially in area $\mathrm{A}$ the variation between species was great.

The mean time spent in one inflorescence ranged from $16.3 \mathrm{sec}(B$. pascuorum) to $32.7 \mathrm{sec}$ ( $B$. lapidarius), but the variation between individuals was great. The time spent per flower ranged from $3.4 \mathrm{sec}$ (B. pascuorum) to $5.5 \mathrm{sec}$ (B. lucorum). The species with a short proboscis stayed in the flowers a little longer than the species with a long proboscis (Fig. 2), but the length of the proboscis was not significantly correlated with the time spent in the flower.

Table 4. Number of differently coloured inflorescences $(b=$ blue, $r=r e d, w=$ white) visited by bumblebee individuals during summer 1989 at Olarinluoma (A) and lirislahti (B).

\begin{tabular}{lrrrrrrrr}
\hline & & \multicolumn{2}{c}{ A } & & \multicolumn{3}{c}{ B } \\
Species & b & r & w & Total & b & $r$ & w & Total \\
\hline luc & 335 & 17 & 3 & 355 & 1225 & 126 & 62 & 1413 \\
lap & 484 & 26 & 9 & 519 & 112 & 15 & 2 & 129 \\
hyp & 10 & - & - & 10 & 138 & 27 & 14 & 179 \\
pas & - & - & - & - & 211 & 20 & 3 & 234 \\
pra & - & - & - & - & 6 & 3 & - & 9 \\
Total & 829 & 43 & 12 & 884 & 1692 & 191 & 81 & 1964 \\
\hline
\end{tabular}

Table 5. Number of movements between differently coloured inflorescences $(b=$ blue, $r=$ red, $w=$ white) by bumblebee individuals during summer 1989 in study areas $A$ and $B$.

\begin{tabular}{lrrrrrrr}
\hline & & A & & & & B & \\
Movements & b & r & w & b & r & w \\
\hline from b to: & 712 & 23 & 6 & 1478 & 81 & 26 \\
from r to: & 28 & 10 & 0 & 74 & 86 & 3 \\
from w to: & 6 & 0 & 3 & 25 & 5 & 35 \\
\hline
\end{tabular}




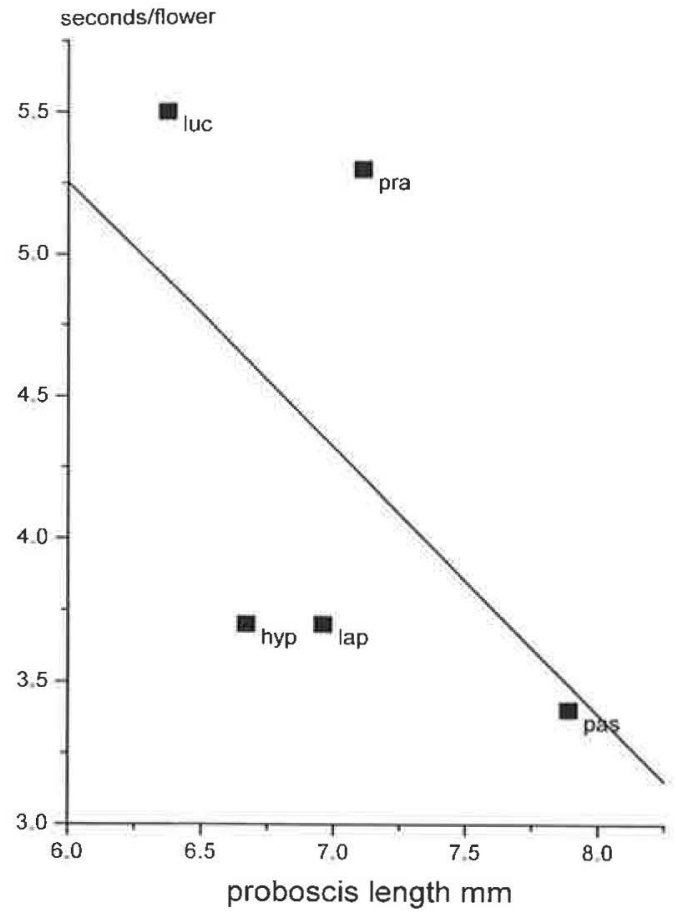

Fig. 2. Relation between proboscis length of workers of different bumblebee species and mean time of visit per lupine flower $(r=0.54 ; n=5)$.

\subsection{Observations in study squares}

When the bumblebees were observed in the study squares, the inflorescence colours selected did not differ significantly from the inflorescence colours offered in the squares having more than one colour (Table 8). The same was true with the behaviour of the commonest species, $B$. lucorum.

The inflorescence colours selected on different observation days differed significantly in study area B (Fig. 3), but the small number of visits to white inflorescences on June 13 may be due to the low number of observations.

The daily distribution of visits was observed both for the study squares and during the individual observations. In the study squares white inflorescences were visited most often in the late afternoon (16:00 hrs) and red inflorescences in the morning (8:00 hrs) and at noon (12:00 hrs). The individual observations showed that the daily distribution of visits to different colour morphs was fairly even (Fig. 4). During these observations white inflorescences were seldom visited in the morning (710:00) and in the evening (19-22:00), while both white and red inflorescences were most often visited in the late afternoon (16-19:00).

Table 6. Number of differently coloured flowers visited by bumblebee species in study areas A and B during summer 1989.

\begin{tabular}{|c|c|c|c|c|c|c|c|c|}
\hline \multirow[b]{2}{*}{ Species } & \multicolumn{3}{|c|}{ A } & \multirow[b]{2}{*}{ Total } & \multicolumn{4}{|c|}{ B } \\
\hline & b & $r$ & $w$ & & $b$ & $r$ & $w$ & Total \\
\hline luc & 2190 & 128 & 33 & 2351 & 9558 & 852 & 395 & 10805 \\
\hline lap & 3628 & 129 & 28 & 3785 & 931 & 119 & 17 & 1067 \\
\hline hyp & 170 & - & - & 170 & 1122 & 188 & 159 & 1469 \\
\hline pas & - & - & - & - & 1169 & 115 & 4 & 1288 \\
\hline pra & - & - & - & - & 19 & 11 & - & 30 \\
\hline Total & 5988 & 257 & 61 & 6306 & 12799 & 1285 & 575 & 14659 \\
\hline
\end{tabular}

Table 7. Mean number ( $\mathrm{S}$ SEM) of inflorescences visited, mean number of flowers visited and mean number of flowers visited per inflorescence by different bumblebee species in study areas A and B during summer 1989.

\begin{tabular}{|c|c|c|c|c|c|c|c|c|c|c|c|c|}
\hline \multirow{3}{*}{\multicolumn{2}{|c|}{$\begin{array}{l}\text { species } \\
\text { mean }\end{array}$}} & \multicolumn{3}{|c|}{ Inflorescences visited } & \multicolumn{3}{|c|}{ Flowers visited } & \multicolumn{5}{|c|}{ Flowers/inflorescences visited } \\
\hline & & \multirow{2}{*}{ A SEM } & \multicolumn{2}{|c|}{ B } & \multicolumn{2}{|c|}{$A$} & \multicolumn{2}{|c|}{$\mathrm{B}$} & \multicolumn{2}{|c|}{ A } & \multicolumn{2}{|c|}{ B } \\
\hline & & & mean & SEM & mean & SEM & mean & SEM & mean & SEM & mean & SEM \\
\hline luc & 9.7 & 1.5 & 14.4 & 1.9 & 67.2 & 13.3 & 110.3 & 17.3 & 6.7 & 0.6 & 7.0 & 0.6 \\
\hline lap & 9.3 & 1.2 & 12.9 & 4.3 & 92.3 & 12.2 & 106.7 & 40.4 & 10.4 & 1.1 & 7.7 & 1.5 \\
\hline hyp & 5.0 & 1.0 & 7.8 & 1.4 & 85.0 & 17.0 & 63.9 & 20.5 & 18.4 & 7.1 & 6.4 & 0.8 \\
\hline pas & - & & 21.3 & 6.6 & - & & 117.1 & 33.8 & - & & 5.3 & 0.6 \\
\hline pra & - & & 4.5 & 0.5 & - & & 15.0 & 2.0 & - & & 3.4 & 0.8 \\
\hline
\end{tabular}




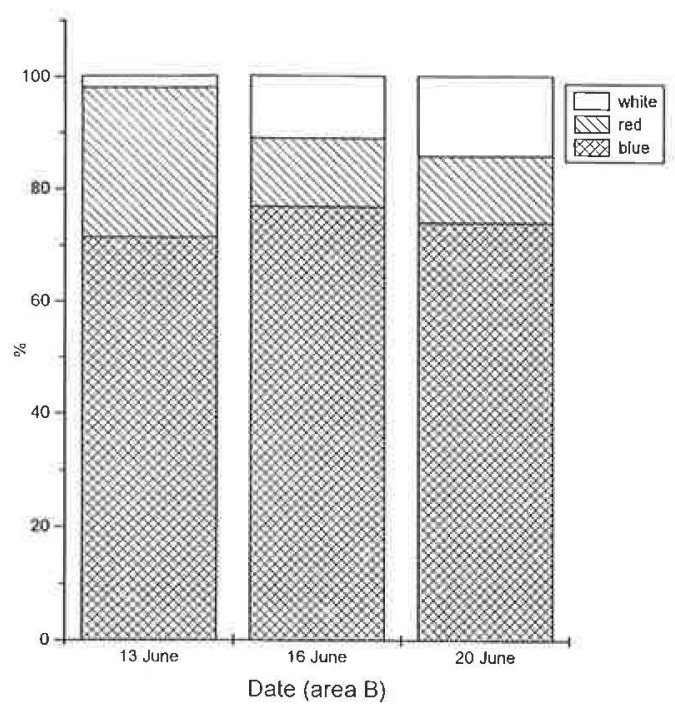

Fig. 3. Proportions of bumblebee visits to differently coloured inflorescences of Lupinus polyphyllus during different observation days in study area B.

\subsection{Weather conditions and colour selection}

The possible effect of weather conditions on inflorescence colour selection was observed during individual observations. At a low temperature (below $15^{\circ} \mathrm{C}$ ) blue inflorescences were visited more often than at the other temperatures, while the proportion of visits to white inflorescences was highest at high temperatures (over $20^{\circ} \mathrm{C}$; Table $9 \mathrm{~A}$ ).

The activity of bumblebees was highest in sunshine hours (Table 9B). White inflorescences were visited proportionally most often in sun-

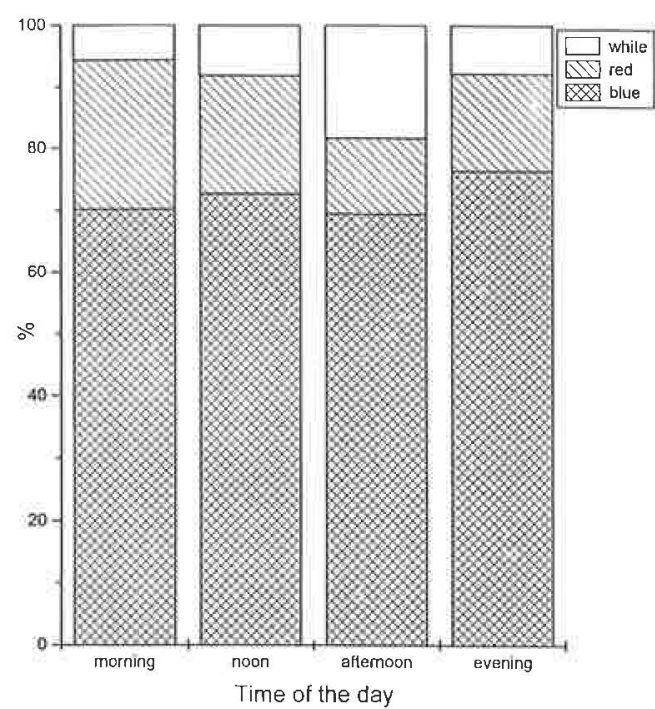

Fig. 4. Proportions of bumblebee visits to differently coloured inflorescences of Lupinus polyphyllus during different times of day in study area B.

shine hours, while the proportion of visits to red inflorescences was highest during overcast hours. The windiness did not seem to much affect colour preferences, although the number of visits to white inflorescences was small in high wind conditions (Table 9C).

The combined effect of weather conditions (Table 10) may partly explain the preference differences observed. When the weather was cloudy, the temperature was usually low and the wind was high, while in sunshine hours the temperature was high and the wind was calm.

Table 8. Number of bumblebees individuals visiting different colour combinations of inflorescences flowering in study squares $(1.5 \times 1.5 \mathrm{~m})$ and comprising all three colour morphs (blue, red and white in proportions: 41:7:10) in 1989.

\begin{tabular}{lrrrrrrrr}
\hline Species & $b$ & $r$ & $w$ & $b+r$ & $b+w$ & $r+w$ & $b+r+w$ & Total \\
\hline luc & 15 & 6 & 5 & 4 & 6 & 2 & 5 & 43 \\
lap & - & - & - & - & - & - & - & - \\
hyp & 2 & 1 & - & 1 & - & - & - & 4 \\
pas & 1 & 1 & - & - & - & - & - & 2 \\
pra & - & - & - & - & - & - & - & - \\
Total & 18 & 8 & 5 & 5 & 6 & 2 & 5 & 49 \\
\hline
\end{tabular}




\section{Discussion}

\subsection{Pollen transfer between Lupinus polyphyllus flowers}

Pollinators are conservative in their food plant choices and avoid unfamiliar plant species (Levin 1978) and hosts with unusual appearances within species (Levin 1972b), even though such plants could be highly profitable. Lupines are not native to Finland, possibly being introduced into Northern Europe in the 17th century (Jalas 1965), but nowadays Lupinus polyphyllus flowers are eagerly visited by bumblebees and honeybees both in Sweden (Jennersten et al. 1988) and in Finland. In our study areas bumblebees were clearly more numerous visitors than honeybees, and so the pollinators most probably affecting the occurrence of different colour morphs are the bumblebees.

The anthers of lupines dehisce before the flower opens (Williams 1987), and thereafter, the pollen is available until the end of the withering of the flower. In Lupinus polyphyllus the pollen is presented on the stigma, and the pollen mass is pushed into the tip of the keel. When the pollinator manipulates a flower, the stigma scoops pollen out through the aperture of the keel and up against the underside of the bee. Pollinators start their visits near the bottom of the inflorescence and move both sideways and upward, although there is more pollen in upper flowers than lower ones, so the movements are not tied to a reward gradient (Haynes \& Mesler 1984, Harder 1990). Pollen removed from flowers by bees is not replenished, but during the visit the small anthers force more pollen towards the tip of the keel, and most of the flowers contain enough pollen for several visits.

Pollen is probably taken from lupine flowers at a relatively constant rate because of the tripping mechanism of the flower. Therefore, the pollen availability does not significantly affect the duration of visits to flowers (at least in Lupinus sericeus, Harder 1990). The pollen which is after grooming packed in corbiculae of the bumblebee and transported to the nest no longer affects the pollination. Less than $1 \%$ of the pollen leaving a flower reaches the stigmas of subsequently visited flowers (Harder \& Thomson 1989), and because of vigorous grooming the proportion may be even smaller after the bees acquire large amounts of pollen (Thomson 1986). However, all the flower visitors we observed had much pollen all over their hairy coat and these pollen grains were available for stigmatic contact.

The amount of cross-pollination seems to be low in many lupine species (Free 1993), although none of the lupine species grown in Finland is completely self-fertilizing (Aniszewski 1993). If we assume that the pollen is transferred only to the next flower, the actual movements from one colour to another would have importance. However, according to Schaal (1980), bumblebees and honeybees carry pollen from Lupinus texensis farther than to the next flower they visit (a1though the mean flight distance of pollinators is about one meter; see also Waser \& Price 1983). If the pollen is carried from the donor to 10 or more flowers (as is the case in Erythronium americanorum, Thomson \& Plowright 1980, and Ipomopsis aggregata, Elam \& Linhart 1988), the gene flow would be much greater (see also Lertzman \& Gass 1983), and the calculations to

Table 8. Number of bumblebees individuals visiting different colour combinations of inflorescences flowering in study squares $(1.5 \times 1.5 \mathrm{~m})$ and comprising all three colour morphs (blue, red and white in proportions: 41:7:10) in 1989.

\begin{tabular}{lrrrrrrrr}
\hline Species & $b$ & $r$ & $w$ & $b+r$ & $b+w$ & $r+w$ & $b+r+w$ & Total \\
\hline luc & 15 & 6 & 5 & 4 & 6 & 2 & 5 & 43 \\
lap & - & - & - & - & - & - & - & - \\
hyp & 2 & 1 & - & 1 & - & - & - & 4 \\
pas & 1 & 1 & - & - & - & - & - & 2 \\
pra & - & - & - & - & - & - & - & - \\
Total & 18 & 8 & 5 & 5 & 6 & 2 & 5 & 49 \\
\hline
\end{tabular}


estimate the effect of pollinators on colour proportions would become much more complicated. On the other hand, the more flowers visited per plant, the smaller will be the pollen carry-over (Levin 1978).

Unfortunately, we do not know how long the Washington lupine pollen can pollinate flowers, or how much pollen is necessary for proper fertilization. We have not found any information on the possible rate of self-incompatability in Lupinus polyphyllus, either.

Table 9. Proportions (\%) of visits paid by bumblebees to differently coloured flower morphs of Lupinus polyphyllus in different conditions of temperature (A), cloudiness $(B)$ and wind $(C)$ in study areas $A$ and $B$ during summer 1989.

A

\begin{tabular}{lrrrr}
\hline Temperature & blue & red & white & All \\
\hline $10-14^{\circ} \mathrm{C}$ & 93.4 & 5.8 & 0.8 & 277 \\
$15-19^{\circ} \mathrm{C}$ & 86.3 & 10.0 & 3.7 & 1579 \\
$20-24^{\circ} \mathrm{C}$ & 87.0 & 8.1 & 4.9 & 840 \\
\hline
\end{tabular}

B

\begin{tabular}{lrrrr}
\hline Cloudiness & blue & red & white & All \\
\hline clear & 87.2 & 8.6 & 4.2 & 1615 \\
$1 / 2$ clouded & 91.1 & 7.8 & 1.1 & 576 \\
overcast & 83.4 & 11.8 & 4.8 & 505 \\
\hline
\end{tabular}

C

\begin{tabular}{lrrrr}
\hline Wind & blue & red & white & All \\
\hline calm & 89.0 & 7.4 & 3.6 & 1295 \\
moderate & 85.6 & 10.8 & 3.6 & 1165 \\
high & 95.3 & 4.2 & 0.4 & 236 \\
\hline
\end{tabular}

\subsection{Flower colour preference of bumblebees}

For the pollinators, nectar and pollen are the most important primary attractants of plants. These attractants are situated in the flowers, which, in turn, advertise themselves with secondary attractants, most often with odours and visual attraction. The two means of visual attraction are the colour and shape of the flowers (Faegri \& Pij1 1979).

Flower colour itself does not have great importance in food plant selection of bumblebees (Brian 1957), although bumblebees may be conditioned to a certain flower colour (Heinrich et al. 1977). In many studies bumblebees have been noticed to prefer a certain flower colour, usually blue (Heinrich et al. 1977, Kevan 1978, Waser \& Price 1981, 1983, Heinrich 1983, Epperson \& Clegg 1987) and purple (Leleji 1973), but also white (Mogford 1974, 1978, Kay 1978) or yellow (Real 1981, Real et al. 1982, Vickery 1992). However, the colour preferences of pollinators may be connected with the flowering time of the plant (Teräs 1976), confusion with neighbouring plant species (Levin \& Kerster 1970, Kay 1978), the shape of the flower (Teräs 1976, 1985, Waser 1983b, Dukas \& Schmida 1989), the reduced colour contrast of flower parts (Waser \& Price 1983), or the rewards offered by the differently coloured flowers (Leleji 1973, Waser 1983a, Cruzan et al. 1988, Delph \& Lively 1989 , Klinkhamer \& de Jong 1990).

In several experiments artificial flowers of different colours have been used to discover the behaviour of pollinators, but in these experiments flower visitors are fed with nectar (sugar syrup; for instance, Heinrich et al. 1977), and the rules observed in nectar-collecting trips may not be comparable to those found in pollen-gathering trips (see Plowright \& Laverty 1984). For exam-

Table 10. Correlations between temperature, humidity, cloudiness and windiness during observation hours in 1989.

\begin{tabular}{lrrrr}
\hline & Temperature & Humidity & Cloudiness & Windiness \\
\hline Temperature & 1.000 & & & \\
Humidity & -.125 & 1.000 & &. \\
Cloudiness & -.576 & 0.189 & 1.000 & \\
Windiness & -.600 & 0.076 & 0.363 & 1.000 \\
\hline
\end{tabular}


ple, bumblebees could revisit the flowers of the same inflorescence because pollen rewards are available despite the earlier visit (see above). On the other hand, when bumblebees collect nectar from flowers having a long corolla tube, the individuals with a long proboscis generally work quicker than individuals with a short proboscis (Heinrich 1979). Similarly, the species which had long proboscis stayed the shortest time in the lupine flowers, although the flowers produce only pollen. The differences between species are so small that the speed of visits most probably does not affect pollination success.

Except for the colour of the flowers, there seemed to be no visible differences between the morphs of the Washington lupine. If bumblebees do not have any innate colour preferences (Waser 1983a) they should select the colour of the first lupine inflorescence to visit randomly. Because bumblebees usually start their visits from the border of a large flower patch, the position of the inflorescence may be of importance. However, our study area $\mathrm{B}$ was small, and area $\mathrm{A}$ was long but narrow (about $70 \times 8 \mathrm{~m}$ ); therefore, the inflorescences growing on the borders of the area should not be favoured due to positions. Bees' random selection of the first colour morph encountered could not be completely verified because the arrival of each individual at the study area was not followed.

If we assume that bumblebees monitor their pollen-collecting success during each flower visit (Harder 1990), they should after the first visit either (1) select the second inflorescence randomly again (as if it is a new individual, Klinkhamer \& de Jong 1990), or (2) keep on visiting the colour chosen the first time (especially if they have received plentiful rewards). The second assumption seemed to be correct, for some individuals made at least three hundred visits to flowers having the same colour. On the other hand, all bumblebees were not strictly bound to one flower colour, for about one half of the individuals changed flower colour during the foraging trip, and $10 \%$ of the individuals visited all three colours. Because individuals were not followed during their whole foraging trips, the proportion of non-constant individuals may be even higher. Among the individuals visiting all three colour morphs during the same trip, the number of the less abundant species, B. hypnorum and B. pascuorum, was greater than expected (in area $B$ ).
The pollinator species and even individual bumblebees may differ in their colour preferences (Kay 1978). For example, the discrimination between yellow-flowered and white-flowered morphs that is shown by many of the insect pollinators of Raphanus raphanistrum plays an important role both in maintaining flower colour polymorphism and in determining the frequency of morphs (Kay 1978). Our observations in area A showed that the commonest bumblebee species selected the colour morphs in the proportions in which they appeared. In the area B the commonest colour (blue) was slightly favoured by all the species except $B$. hypnorum which visited the white morph significantly more often than did the other species. This exceptional behaviour was not observed in area $\mathrm{A}$, where the few $B$. hypnorum individuals did not visit white flowers at all, and therefore the reason for their behaviour remains unknown.

$B$. lapidarius seemed to avoid white lupine flowers, which might be significant for their pollination success, if $B$. lapidarius is the most numerous pollinator in the area. However, at least in area $\mathrm{B}$, the numbers of $B$. lucorum were much higher than those of $B$. lapidarius, and the avoidance of one colour morph by the latter species should not affect the colour proportions. On the other hand, different bumblebee species may carry different amounts of pollen.

It cannot be excluded that the alleles affecting flower colour may also have an effect on other properties of the flower. The pollen from differently coloured flowers may have dissimilar odours (see Olesen \& Knudsen 1994), and the longevity of pollen grains or the speed of pollen tube growth may differ and cause bias in pollination success. Moreover, the differently coloured flowers may produce different amounts of pollen or seeds, although these kinds of differences in other plants do not provide evidence for colourrelated reproductive success (Elam \& Linhart 1988).

\subsection{Weather and time}

When the temperature is high, the flowers producing only pollen are said to be preferred over flowers giving both pollen and nectar; and at low 
temperatures, vice versa (Powell \& Jones 1983). These preferences should not affect the colour preferences within species. However, when the temperature was high, white flowers were visited more often than expected while blue flowers were preferred at low temperatures (that is, in the beginning of the observation period). Also, blue flowers were visited most often in high-wind conditions. However, the effect of these weather factors seemed to be of minor importance in the colour preferences of bumblebees. Similarly, Mogford (1978) reported that although the numbers of foragers visiting Cirsium palustre are reduced dramatically by unfavourable weather conditions, the relative proportions of the various colour types present appears unaffected.

The visual conspicuousness of a flower to a foraging insect clearly depends not only on the colour of the flower itself but also on the contrast with its surroundings (Barth 1985). The contrast with the background for blue and purple flowers is less than for other colours (Kevan 1978), and bumblebees may distinguish light flowers better than dark ones at twilight or in other conditions of darkness (Hulkkonen 1928). Therefore, white flowers should have been favoured in the evening and during overcast periods. However, in the evening blue flowers were selected and in the overcast periods red flowers were visited more often than expected. White inflorescences were favoured in the afternoon, and red in the morning. These preferences may be important, if weather conditions are poor in the beginning or the end of the summer or at different times of the day. However, the differences should be much greater than observed if they are to affect colour proportions.

Early flowers increase visitation to later flowers produced by the same plant (Thomson 1985), and, therefore, the learned "searching image" should favour later flowering red and white flowers over the blue flowers which seemed to be the first to start flowering. However, we could not determine this.

\subsection{Colour morphs and pollinator behaviour}

Pollinators may act as strong selective agents upon balanced flower colour polymorphism (Levin 1972a, Kay 1978). In Lupinus polyphyllus, the gene causing blue flowers is said to be dominant, whereas genes causing red and white show no dominance over each other. Therefore, if the movement of pollinators from blue to other colours is common, the blue morph is favoured and may become the only one in the population.

If pollinators move between flowers of the same colour the different morphs have greater chances to survive in the population. According to our observations, half the pollinators seem to prefer the same colour during their foraging trips, which therefore favours the survival of rare colour morphs. However, the preference may not be strong enough to maintain the existing proportions of red and white. On the other hand, we could not observe that these rare morphs of Lupinus polyphyllus would have been strongly under-visited, although this seems to be a rule with many other species (see Leleji 1973, Epperson \& Clegg 1987) and may cause higher rates of self-pollination (Epperson \& Clegg 1987), especially among late-produced seeds (Jennersten et al. 1988).

Because blue inflorescences had more flowers than did the other colour morphs, the proportion of blue flowers visited in each study area was slightly higher than the proportion of blue inflorescences visited. White inflorescences had the smallest number of flowers, and those flowers seemed to drop easily. Therefore, the production of pods in white inflorescences was low, and reproduction was weak, which seemed to keep the numbers of white inflorescences low. On the other hand, the searching image of white inflorescences may have changed due to early dropping of flowers (cf. Gori 1983).

In Finland, Lupinus polyphyllus usually grows near human dwellings, and so the proportions of colour morphs are, at least partly, affected by human activities (especially flower picking). There also seemed to be differences in flower numbers and pod formation between colour morphs. There may be differences in self-pollination rate and vegetative growth potential or in the ability to occupy new areas (Stanton 1987) which may all favour, for instance, blue inflorescences independent of pollinator behaviour.

The amount of outcrossing between the lupine colour morphs is hard to demonstrate. The general rule seemed to be that different coloured inflorescences were visited approximately in the 
proportions they appeared, and that the colour selected by an individual bumblebee at the beginning of the trip was favoured during the whole trip. In many cases the nearest inflorescence having another colour was skipped. It seems to us that the behaviour of foraging bumblebees favours the existing proportions of different colour morphs in the lupine population.

Acknowledgements. We would like to express our gratitude to Marko Laine and Hannu Pietiäinen for their help in statistical treatment of the material.

\section{References}

Aniszewski, T. 1993: Lupine: a potential crop in Finland. Studies on the ecology, productivity and quality of Lupinus spp. - Univ. Joensuu Publ. Sci. 29:1-50.

Barth, F. G. 1985: Insects and flowers. The biology of partnership. - Princeton Univ. Press, Princeton, 297 pp.

Brian, A. D. 1957: Differences in the flowers visited by four species of bumblebees and their causes. - J. Anim. Ecol. 26:71-96.

Cruzan, M. B., Neal, P. R. \& Willson, M. F. 1988: Floral display in Phyla incisa: consequences for male and female reproductive success. - Evolution 42:505-515.

Daumer, K. 1958: Blumenfarben, wie sie die Bienen sehen. - Zeitschr. Vergl, Physiol. 41:49-110.

Delph, L. F. \& Lively, C. M. 1989: The evolution of floral color change: pollinator attraction versus physiological constraints in Fuchsia excorticata. - Evolution 43:1252-1262.

Dukas, R. \& Shmida, A. 1989: Correlation between the color, size and shape of Israeli crucifer flowers and relationships to pollinators. - Oikos 54:281-286.

Dunn, D. B. 1956: The breeding systems of Lupinus, Group Micranthi. - Am. Midl. Nat. 55:443-472.

Elam, D. R. \& Linhart, Y. B. 1988: Pollination and seed production in Ipomopsis aggregata: differences among and within flower color morphs. - Amer. J. Botany 75:1262-1274.

Epperson, B. K. \& Clegg, M. T. 1987: Frequency-dependent variation for outcrossing rate among flower color morphs of Ipomoea purpurea. - Evolution 41:1302-1311.

Faegri, K. \& Pijl, L. van der 1979: The principles of pollination ecology. 3. ed. - Pergamon Press, Oxford, 291 pp.

Free, J. B. 1993: Insect pollination of crops. 2. ed. Academic Press, London, 684 pp.

Gori, D. F. 1983: Post-pollination phenomena and adaptive floral changes. - In Jones, C. E. \& Little, R. J. (eds.): Handbook of experimental pollination biology, pp. 31-45. Van Nostrand Reinhold, New York.

Harder, L. D. 1990: Behavioral responses by bumble bees to variation in pollen availability. - Oecologia 85:41-47.

Harder, L. D. \& Thomson, J. D. 1989: Evolutionary options for maximizing pollen dispersal of animal-polli- nated plants. - Am. Nat. 133:323-344.

Haynes, J. \& Mesler, M. 1984: Pollen foraging by bumblebees: Foraging patterns and efficiency on Lupinus polyphyllus. - Oecologia 61:249-253.

Heinrich, B. 1979: Bumblebee economics, - Harvard Univ. Press, Cambridge, Mass., 245 pp.

- 1983: Insect foraging energetics. - In Jones, C. E. \& Little, R. J. (eds.): Handbook of experimental pollination biology, pp. 187-214. Van Nostrand Reinhold, New York.

Heinrich, B., Mudge, P. R. \& Deringis, P. G. 1977: Laboratory analysis of flower constancy in foraging bumblebees: Bombus ternarius and B. terricola. - Behav. Ecol. Sociobiol. 2:247-265.

Hulkkonen, O. 1928: Zur Biologie der südfinnischen Hummeln. - Ann. Univ. Aboensis A, 3 (1):1-81.

Jalas, J. 1965: Lupinus L. - Lupiinin suku. — In Jalas, J. (ed.): Suuri Kasvikirja 2, pp. 807-810. Otava, Helsinki.

Jennersten, O., Berg, L. \& Lehman, C. 1988: Phenological differences in pollinator visitation, pollen deposition and seed set in the sticky catchfly, Viscaria vulgaris. — J. Ecol. 76:1111-1132.

Kay, Q. O. N. 1978: The role of preferential and assortative pollination in the maintenance of flower colour polymorphisms. - In Richards, A. J. (ed.): The pollination of flowers by insects, pp. 175-190. Academic Press, London.

Kevan, P. G. 1978: Floral coloration, its colorimetric analysis and significance in anthecology. - In Richards, A. J. (ed.): The pollination of flowers by insects, pp. 5178. Academic Press, London.

Klinkhamer, P. G. L. \& de Jong, T. J. 1990: Effects of plant size, plant density and sex differential nectar reward on pollinator visitation in the protandrous Echium vulgare (Boraginaceae). — Oikos 57:399-405.

Langridge, D. F. \& Goodman, R. D. 1977: A study of pollination of lupins (Lupinus angustifolius). - Australian J. Exp. Agric. Animal Husbandry 17:319-322.

Leleji, O. I. 1973: Apparent preference by bees for different flower colours in cowpeas (Vigna sinensis (L.) Savi ex Hassk.). - Euphytica 22:150-153.

Lertzman, K. P. \& Gass, C. L. 1983: Alternative models of pollen transfer. - In Jones, C. E. \& Little, R. J. (eds.): Handbook of experimental pollination biology, pp. 474-489. Van Nostrand Reinhold, New York.

Levin, D. A. 1972a: The adaptedness of corolla-color variants in experimental and natural populations of Phlox drummondii. - Amer. Nat. 106:57-70.

- 1972b: Low frequency disadvantage in the exploitation of pollinators by corolla variants in Phlox. Amer. Nat. 106:453-460.

- 1978: Pollinator behaviour and the breeding structure of plant populations. - In Richards, A. J. (ed.): The pollination of flowers by insects, pp. 133-150. Academic Press, London.

Levin, D. A. \& Kerster, H. W. 1970: Phenotypic dimorphism and populational fitness in Phlox. - Evolution 24:128-134. 
Mogford, D. J. 1974: Flower colour polymorphism in Cirsium palustre. 2. Pollination. - Heredity 33:257-263.

- 1978: Pollination and flower colour polymorphism, with special reference to Cirsium palustre. - In Richards, A. J. (ed.): The pollination of flowers by insects, pp. 191-199. Academic Press, London.

Olesen, J. M. \& Knudsen, J. T. 1994: Scent profiles of flower colour morphs of Corydalis cava (Fumariaceae) in relation to foraging behaviour of bumblebee queens (Bombus terrestris). - Biochemical Systematics and Ecology 22:231-237.

Pekkarinen, A. 1979: Morphometric, colour and enzyme variation in bumblebees (Hymenoptera, Apidae; Bombus) in Fennoscandia and Denmark. - Acta Zool. Fennica 158:1-60.

Plowright, R. C. \& Laverty, T. M. 1984: The ecology and sociobiology of bumble bees. - Ann. Rev. Entomol. 29:175-199.

Powell, E. A. \& Jones, C. E. 1983: Floral mutualism in Lupinus benthamii (Fabaceae) and Delphinium parryi (Ranunculaceae). - In Jones, C. E. \& Little, R. J. (eds): Handbook of experimental pollination biology, pp. 310-329. Van Nostrand Reinhold, New York.

Real, L. A. 1981: Uncertainty and pollinator-plant interactions: the foraging behavior of bees and wasps on artificial flowers. - Ecology 62:20-26.

Real, L. A., Ott, J. \& Silverfine, E. 1982: On the tradeoff between the mean and the variance in foraging: effect of spatial distribution and color preference, - Ecology 63:1617-1623.

Schaal, B. A. 1980: Measurement of gene flow in Lupinus texensis. - Nature 284:450-451.

Stanton, M. 1987: Reproductive biology of petal color variants in wild populations of Raphanus sativus L.: I. Pollinator response to color morphs, - Amer. J. Bot.
$74: 176-185$.

Teräs, I. 1976: Flower visits of bumblebees, Bombus Latr. (Hymenoptera, Apidae), during one summer. - Ann. Zool. Fennici 13:200-232.

- 1985: Food plants and flower visits of bumblebees (Bombus: Hymenoptera, Apidae) in southern Finland. - Acta Zool. Fennica 179:1-120.

Thomson, J. D. 1985: Pollination and seed set in Diervilla lonicera (Caprifoliaceae): temporal patterns of flower and ovule deployment. - Amer. J. Bot. 72:737-740.

- 1986: Pollen transport and deposition by bumble bees in Erythronium: influences of floral nectar and bee grooming. - J. Ecol. 74:329-341.

Thomson, J. D. \& Plowright, R. C. 1980: Pollen carryover, nectar rewards, and pollinator behavior with special reference to Diervilla lonicera. - Oecologia 46:68-74.

Vickery, R. K. Jr. 1992: Pollinator preferences for yellow, orange, and red flowers of Mimulus verbenaceus and M. cardinalis. - Great Basin Naturalist 52:145-148.

Waser, N. M. 1983a: The adaptive nature of floral traits: Ideas and evidence. - In Real, L. (ed.): Pollination biology, pp. 241-285. Academic Press, Orlando.

- 1983b: Competition for pollination and floral character differences among sympatric plant species: a review of evidence. - In Jones, C. E. \& Little, R. J. (eds.): Handbook of experimental pollination biology, pp. 277-293. Van Nostrand Reinhold, New York.

Waser, N. M. \& Price, M. V. 1981: Pollinator choice and stabilizing selection for flower color in Delphinium nelsonii. - Evolution 35:376-390.

- 1983: Pollinator behaviour and natural selection for flower colour in Delphinium nelsonii. - Nature 302:422-424.

Williams, I. H. 1987: The pollination of lupins. - Bee World 68:10-16. 